\title{
Evaluasi Sistem Manajemen Pengetahuan Di PT Telekomunikasi Selular Palembang
}

\author{
Knowledge Management System Evaluation in PT Telekomunikasi \\ Selular Palembang
}

ARGA WIRADARMA ${ }^{1 *}$, HENDRA SURYA DINATA

\begin{abstract}
Abstrak
Tujuan penelitian ini adalah melakukan analisis permasalahan dan evaluasi terhadap sistem manajemen pengetahuan di PT Telkomsel Palembang. Penelitian ini diharapkan mampu memberikan rekomendasi kepada PT Telkomsel dalam meningkatkan penggunaan dan pemanfaatan sistem manajemen pengetahuan yang sedang digunakan saat ini. Metode penelitian yang kami gunakan meliputi studi literatur, pengumpulan data, dan metode manajemen pengetahuan, yaitu metode Fit/Gap Analysis (FGA). Hasil yang dicapai berupa evaluasi dan rekomendasi sistem dari sistem manajemen pengetahuan sebagai solusi dalam menjawab permasalahan yang dihadapi oleh PT. Telkomsel Palembang. Setelah melakukan evaluasi, diketahui bahwa PT. Telkomsel Palembang perlu membuat fitur notifikasi posting sebagai pengingat kewajiban pengguna untuk melakukan posting knowledge, juga sebagai sarana interaksi antara admin kepada pengguna, menyederhanakan sistem approval idea/inovation untuk mempersingkat waktu, dan mengurangi beban kerja admin dalam mengizinkan berbagai macam aktivitas di dalam KMS.
\end{abstract}

Kata Kunci: fit/gap analysis, sistem manajemen pengetahuan, risk analysis ranking, tabel probability-impact matrix.

\begin{abstract}
The research purposes is to analyze and to evaluate the knowledge management system of PT. Telkomsel Palembang. We expect to be able to provide recommendations to the PT. Telkomsel to improve the use of current application. The methodology that we used includes the study of literature, data collection and the Fit/Gap Analysis (FGA). The results of this final assignment is evaluation and recommendation for the current system of knowledge management as a solution in answering the problems faced by PT. Telkomsel Palembang. We recommend that PT. Telkomsel Palembang needs to create a reminder notification feature user obligation to post knowledge as well as a means of interaction between the admin to user, simplifying the approval system of idea/innovation to shorten the time and reduce the workload of administrators on allowing many kind activities in the KMS.
\end{abstract}

Keywords: fit/gap analysis, knowledge management system, probability table-impact matrix, risk analysis ranking.

\section{PENDAHULUAN}

Manajemen pengetahuan semakin tidak terbantahkan kebutuhannya terhadap perkembangan organisasi. Munculnya manajemen pengetahuan dilatarbelakangi oleh keyakinan akan besarnya manfaat pengetahuan bagi organisasi. Dengan memiliki manajemen pengetahuan yang baik, pengelolaan organisasi menjadi lebih efektif dan efisien. Hal ini dikarenakan pengetahuan ini memuat penciptaan, cara-cara memperoleh, pengelolaan, berbagi, dan aplikasi (Dalkir dan Beaulieu 2017). Pada tingkat berbagi dan aplikasi, manajemen pengetahuan akan bisa dirasakan manfaatnya, ketika hasil karya bisa dirasakan langsung oleh

${ }^{1}$ Departemen Ilmu Komputer IPB;

*Penulis Korespondensi: Surel: argawiradarma@ipb.ac.id 
masyarakat. Pengetahuan ini akan meresap pemakaiannya untuk pengembangan Sumber Daya Manusia (SDM). Pengetahuan manajemen dianggap sebagai pemicu SDM dalam arena persaingan (Dalkir 2011).

Sistem manajemen pengetahuan, atau knowledge management system (KMS) adalah sistem yang dibuat untuk mengolah pengetahuan seperti menyimpan, mencari, mengatur dan menggunakan kembali pengetahuan yang ada (Nazari dan Emami 2012). KMS dapat membantu perusahaan dalam mencapai tujuannya jika digunakan dengan baik dan efektif. KMS dapat membantu karyawan saling berbagi pengetahuan satu dengan yang lain dan dapat membantu manajer untuk berbagi pengetahuan dengan karyawannya (Sari dan Tania 2014). Dengan cara tersebut, perusahaan dapat meningkatkan pengetahuan karyawannya, mempercepat proses kerja, dan mempermudah penyebaran pengetahuan ke seluruh karyawan.

PT Telekomunikasi Selular atau biasa disebut Telkomsel adalah salah satu perusahaan operator telekomunikasi seluler terbesar di Indonesia. Pada awal berdirinya, perusahaan ini bergerak di bidang Telekomunisasi. Untuk menjawab perkembangan bisnis dan pasar saat ini, Telkomsel sekarang sudah bertransformasi ke perusahaan Telko Digital. Tidak hanya bergerak di bidang Telekomunikasi, tetapi juga bergerak di bidang Digital. Dengan semakin berkembangnya PT Telkomsel dan semakin bertambahnya jumlah karyawan yang ada, perusahaan membutuhkan sebuah KMS yang membantu para karyawan untuk dapat mentransfer pengetahuan antar sesama karyawan.

PT Telkomsel kemudian mengembangkan aplikasi KMS bernama Lentera (Learning Through Exploration) pada tahun 2016. Dari hasil observasi, aplikasi ini belum banyak digunakan oleh karyawan dalam melakukan berbagi pengetahuan (knowledge sharing). Dari 4900-an karyawan Telkomsel, hanya 1800-an karyawan yang melakukan berbagi pengetahuan di aplikasi Lentera. Secara presentase baru sekitar $36.7 \%$ karyawan yang melakukan berbagi pengetahuan di aplikasi Lentera ini. Hal ini menjadi salah satu dasar perlunya dilakukan evaluasi terhadap KMS PT Telkomsel. Tujuan penelitian ini adalah melakukan analisis permasalahan terhadap KMS di PT Telkomsel, dan memberikan rekomendasi kepada PT Telkomsel dalam meningkatkan penggunaan dan pemanfaatan KMS.

\section{METODE}

Dalam tahap ini dilakukan peninjauan terhadap KMS PT. Telkomsel dengan melakukan evaluasi menggunakan metode Fit/Gap Analysis (FGA) untuk menemukan, menganalisis, dan mengidentifikasi fit dan gap (Jackson et al. 2011; Pajk dan Kovacic 2013). Penelitian ini juga melakukan risk analysis terhadap gap yang ditemukan dengan tabel risk analysis ranking maupun tabel probability-impact matrix (Verma dan Dhanda 2016). Metode Fit/Gap Analysis digunakan agar dapat mengidentifikasi kebutuhan dari Tim Human Capital Management, apakah aplikasi Lentera sudah memenuhi kebutuhan proses bisnis yang dibutuhkan. Risk Analysis dilakukan untuk mengidentifikasi resiko yang akan mungkin terjadi jika rekomendasi yang telah dibuat tidak diimplementasikan oleh Tim Human Capital Management Telkomsel (Verma dan Dhanda 2016).

\section{Data Penelitian}

Data penelitian yang digunakan adalah data mengenai kebutuhan yang telah dirancang untuk membuat KMS Lentera. Kebutuhan ini merupakan landasan fungsionalitas dalam membangun KMS tersebut. Kebutuhan ini berjumlah 25 dan digolongkan kepada 5 proses. Kebutuhan untuk process my knowledge/my idea dan my mileage dapat dilihat pada Tabel 1.

\section{Tahapan Penelitian}

Penelitian ini terdiri atas beberapa tahapan, yaitu pengumpulan data, fit/gap analysis, risk analysis dan pemberian rekomendasi. Tahapan penelitian dapat dilihat pada Gambar 1 . 
Tabel 1 Kebutuhan KMS Lentera

\begin{tabular}{cl}
\hline Proses & \multicolumn{1}{c}{ Requirement } \\
\hline My knowledge/My Idea & Melihat daftar knowledge/Idea user yang sudah dipublish \\
& Revisi knowledge \\
My Mileage & Top Learner (Mileage) \\
& Melihat Point/Mileage \\
\hline
\end{tabular}

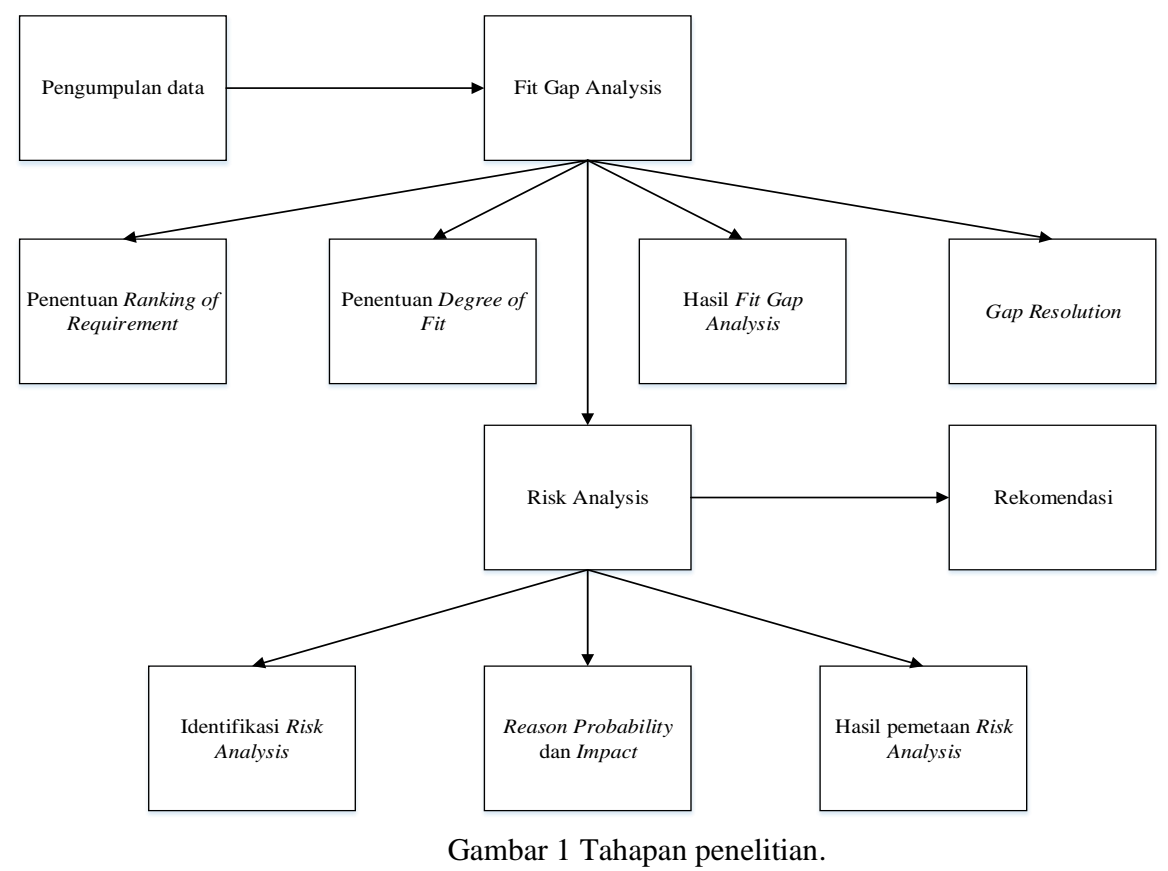

\section{Pengumpulan Data}

Pengumpulan data dilakukan untuk mengetahui kebutuhan sistem yang akan dibangun. Pengumpulan data yang dilakukan menggunakan dua cara, yaitu:

- Observasi:dilalukan untuk melihat secara langsung bagaimana knowledge didapat, ditransfer, dan digunakan di perusahaan. Obsevasi dilakukan dengan melibatkan salah satu penulis yang bekerja di PT. Telkomsel sebagai perusahaan yang sedang diteliti.

- Wawancara: dilakukan dengan mewawancarai langsung Manajer Human Capital Operation Sumatera dari PT. Telkomsel, sehingga dapat diketahui proses bisnis, data-data, SOP, dan fungsi-fungsi yang terdapat pada KMS yang digunakan.

\section{Penentuan Degree of Fit}

Untuk menentukan kesesuaian antara sistem berjalan dengan proses bisnis yang ada pada perusahaan dibagi menjadi 3 level, yaitu Fit, Gap dan Partial. Hasil analisa Degree of Fit pada KMS Lentera dapat dilihat pada Tabel 2.

\section{HASIL DAN PEMBAHASAN}

\section{Hasil Fit/Gap Analysis}

Hasil dari Fit/Gap Analysis dapat dilihat pada Tabel 3. Berdasarkan hasil perhitungan Fit/Gap Analysis pada Tabel 3, dapat disimpulkan bahwa KMS pada PT. Telkomsel memiliki Degree of Fit sebesar 80\%, Degree of Gap sebesar 8\%, dan Degree of Partial sebesar 12\%. Sehingga dibutuhkan beberapa perbaikan agar sistem dapat digunakan secara optimal dan lebih baik dalam fungsinya untuk memenuhi kebutuhan pengguna. 


\section{Gap Resolution}

Berdasarkan hasil dan kesimpulan dari Fit/Gap Analysis dan degree of fit diatas, maka rekomendasi akan difokuskan kepada 3 requirement dengan kategori Low dan High yang belum dapat dipenuhi oleh sistem. Salah satu requirement yang difokuskan dapat dilihat pada Tabel 4.

\section{Risk Analysis}

Setelah didapatkan hasil dari Fit/Gap Analysis maka untuk selanjutnya perlu dilakukan risk analysis untuk meneliti lebih lanjut mengenai dampak atau resiko yang akan muncul jika rekomendasi yang diberikan untuk company requirement tidak diterapkan. Risk analysis akan diterapkan kepada company requirement yang memiliki degree of fit Gap dan Partial. Pada risk analysis terdapat dua penilaian yang digunakan setelah resiko yang ada pada company requirement teridentifikasi, yang pertama adalah mengukur tingkat kemungkinan resiko tersebut terjadi atau probability. Cara penilaian probability adalah dengan menentukan peringkatnya sesuai deskripsi pada Tabel 5. Penilaian berikutnya yang dilakukan setelah

Tabel 2 Analisis kebutuhan Degree of Fit

\begin{tabular}{|c|c|c|c|c|c|c|}
\hline No & Requirement & Description & Rank & $\begin{array}{c}\text { Degree } \\
\text { of Fit }\end{array}$ & Evaluation & Recomendation \\
\hline \multicolumn{7}{|c|}{ Search/Inquiry (home) } \\
\hline 1.1 & $\begin{array}{l}\text { Search Menu, } \\
\text { user bisa } \\
\text { mengetahui } \\
\text { posisi } \\
\text { knowledge } \\
\text { yang dicari }\end{array}$ & $\begin{array}{l}\text { Pada search menu } \\
\text { ini, setiap } \\
\text { pengguna bisa } \\
\text { mencari } \\
\text { knowledge/idea } \\
\text { dari pengguna } \\
\text { yang lain }\end{array}$ & $\mathrm{H}$ & $\mathrm{F}$ & $\begin{array}{l}\text { Pada Aplikasi } \\
\text { Lentera, search } \\
\text { menu untuk mencari } \\
\text { knowledge/idea } \\
\text { terdapat di setiap } \\
\text { kategori menu } \\
\text { Knowledge Center } \\
\text { maupun Idea } \\
\text { Factory }\end{array}$ & - \\
\hline
\end{tabular}

Keterangan:

1 Company requirement merupakan fitur-fitur apa saja yang ada pada sistem dan dibutuhkan oleh pengguna untuk membantu pekerjaan mereka

2 Description merupakan penjelasan secara mendetail mengenai bagaimana fitur-fitur dari Company Requirement digunakan oleh pengguna

3 Rank merupakan tingkat kepentingan maupun prioritas dari company requirement dalam sistem. Terbagi atas High, Medium, dan Low.

4 Degree of fit merupakan status yang mewakili kondisi pada sebuah requirement. Adapun kondisi kondisi dari degree of fit dapat dibagi menjadi 3, yakni: Fit yaitu sesuai, Gap berarti belum sesuai, dan Partial yakni belum berguna sepenuhnya sehingga harus dikembangkan.

5 Evaluation merupakan penjelasan lebih mendalam mengenai kondisi sebuah requirement.

6 Recomendation merupakan saran mengenai apa saja langkah-langkah yang harus dilakukan agar requirement yang berstatus Partial maupun Gap agar bisa diubah menjadi Fit.

Tabel 3 Hasil Fit/Gap Analysis

\begin{tabular}{cccc}
\hline Rank & Fit & Gap & Partial Gap \\
\hline High & $72 \%$ & & $12 \%$ \\
& $\left(18 / 25^{*} 100 \%\right)$ & & $\left(3 / 25^{*} 100 \%\right)$ \\
Medium & $8 \%$ & & \\
Low & $\left(2 / 25^{*} 100 \%\right)$ & $8 \%$ & \\
Total & & $(2 / 25 * 100 \%)$ & $12 \%$ \\
\hline
\end{tabular}

Tabel 4 Gap Resolution periode penyimpanan dan retensi

\begin{tabular}{|c|c|c|c|c|c|}
\hline Requirement & Description & Rank & $\begin{array}{c}\text { Degree } \\
\text { of Fit }\end{array}$ & Evaluation & Description \\
\hline $\begin{array}{l}\text { Periode } \\
\text { penyimpanan: } \\
\text { Tentukan periode } \\
\text { retensi saat } \\
\text { mendaftar } \\
\text { pengetahuan }\end{array}$ & $\begin{array}{l}\text { Menentukan } \\
\text { periode } \\
\text { penyimpanan dari } \\
\text { knowledge yang } \\
\text { akan di submit }\end{array}$ & $\mathrm{L}$ & G & $\begin{array}{l}\text { Tidak terdapat } \\
\text { kolom dalam } \\
\text { menentukan } \\
\text { periode } \\
\text { penyimpanan } \\
\text { knowledge }\end{array}$ & $\begin{array}{l}\text { Melihat pentingnya } \\
\text { knowledge tersimpan, } \\
\text { direkomendasikan } \\
\text { tidak ada penentuan } \\
\text { periode penyimpanan }\end{array}$ \\
\hline
\end{tabular}


probability adalah Impact yang menyatakan status dampak yang akan muncul jika rekomendasi tidak diterapkan. Peringkat dalam menyatakan impact pada suatu company requirement dapat dilihat pada Tabel 6 .

\section{Hasil Identifikasi Risk Analysis}

Hasil Risk Analysis digunakan untuk mengukur kemungkinan terjadi dan dampak resiko dari resiko requirement yang telah diidentifikasi. Salah satu hasil yang didapatkan dapat dilihat pada Tabel 7.

\section{Reason for Probability dan Impact pada hasil Risk Analysis}

Hasil alasan pemberian kategori High, Medium dan Low pada probability dan impact pada hasil risk analysis dapat dilihat pada Tabel 8.

Tabel 5 Risk Probability Rank

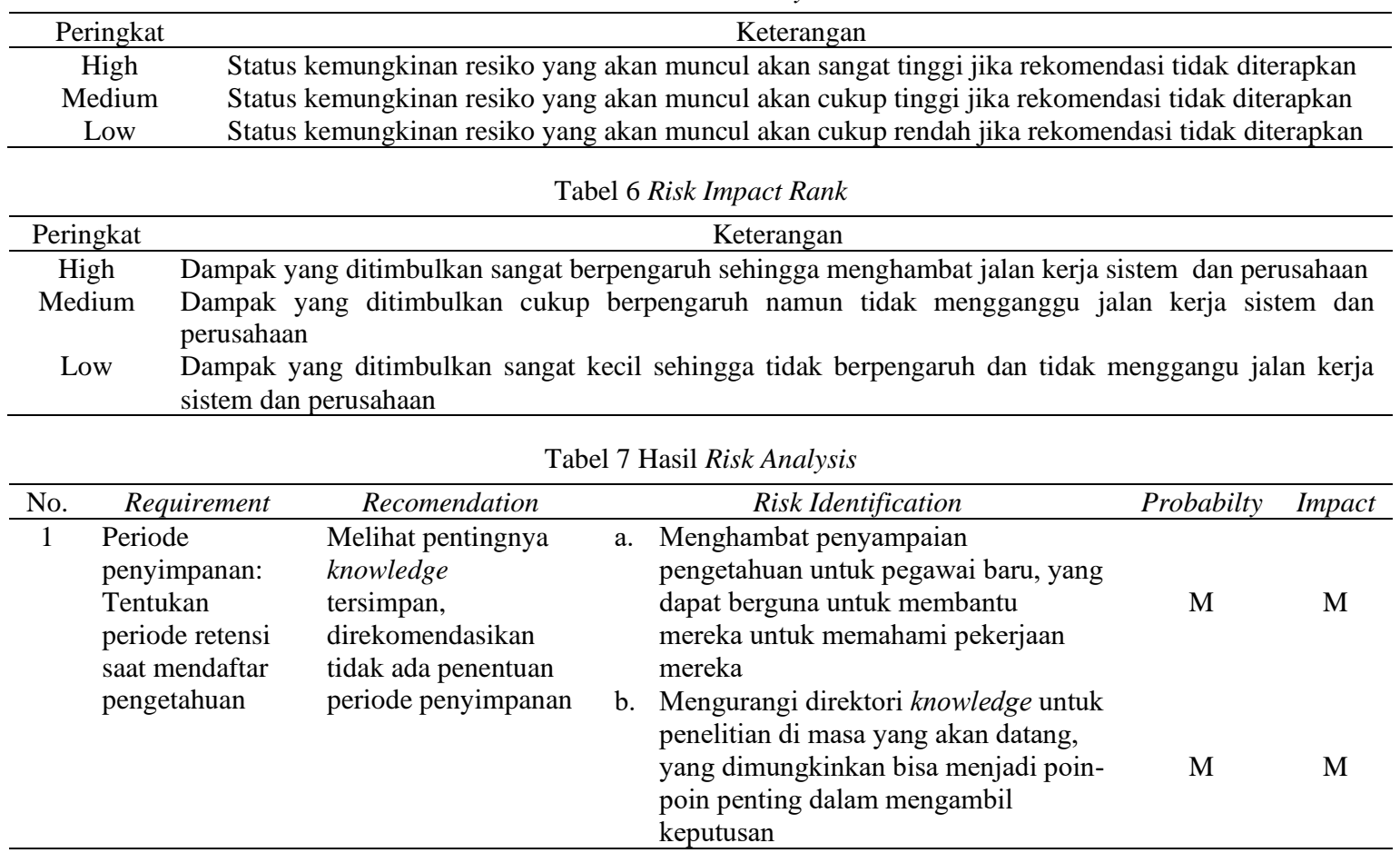

Tabel 8 Reason untuk hasil Risk Analysis

\begin{tabular}{|c|c|c|c|c|c|c|}
\hline No & Requirement & Risk Identification & Probability & Reason for Probability & Impact & Reason for Impact \\
\hline \multirow[t]{2}{*}{1} & \multirow[t]{2}{*}{$\begin{array}{l}\text { Periode } \\
\text { penyimpanan: } \\
\text { Tentukan } \\
\text { periode } \\
\text { retensi saat } \\
\text { mendaftar } \\
\text { pengetahuan }\end{array}$} & $\begin{array}{l}\text { a. Menghambat } \\
\text { penyampaian } \\
\text { pengetahuan untuk } \\
\text { pegawai baru, yang } \\
\text { dapat berguna untuk } \\
\text { membantu mereka } \\
\text { untuk memahami } \\
\text { pekerjaan mereka }\end{array}$ & M & $\begin{array}{l}\text { Pegawai baru yang } \\
\text { menggunakan dapat } \\
\text { melihat knowledge yang } \\
\text { baru di-posting namun } \\
\text { tidak dapat melihat } \\
\text { knowledge yang telah } \\
\text { di-posting terdahulu }\end{array}$ & M & $\begin{array}{l}\text { Knowledge yang } \\
\text { tersimpan akan } \\
\text { terhapus sesuai periode } \\
\text { yang ditetapkan, } \\
\text { namun masih bisa } \\
\text { dicegah dengan rekap } \\
\text { manual tetapi akan } \\
\text { memakan lebih banyak } \\
\text { waktu }\end{array}$ \\
\hline & & $\begin{array}{l}\text { b. Mengurangi } \\
\text { direktori knowledge } \\
\text { untuk penelitian di } \\
\text { masa yang akan } \\
\text { datang, yang } \\
\text { dimungkinkan bisa } \\
\text { menjadi poin-poin } \\
\text { penting dalam } \\
\text { mengambil } \\
\text { keputusan }\end{array}$ & M & $\begin{array}{l}\text { Knowledge yang } \\
\text { tersimpan pada KMS } \\
\text { akan terbatas untuk } \\
\text { knowledge yang baru } \\
\text { di-posting saja dan } \\
\text { dengan jangka waktu } \\
\text { tertentu }\end{array}$ & M & $\begin{array}{l}\text { Knowledge yang } \\
\text { terkumpul pada } \\
\text { aplikasi KMS dapat } \\
\text { dimanfaatkan untuk } \\
\text { keperluan jangka } \\
\text { panjang semisal } \\
\text { penelitian, namun jika } \\
\text { di hapus maka hal } \\
\text { tesebut tidak dapat } \\
\text { dilakukan sama sekali } \\
\end{array}$ \\
\hline
\end{tabular}




\section{Hasil Pemetaan Risk Analysis}

Setelah didapatkan hasil dari Risk Analysis, maka langkah berikutnya yang harus dilakukan adalah membuat probability-impact matrix guna merangkap semua data yang didapatkan dari penelitian tersebut. Untuk penulisannya probability akan dituliskan secara vertikal dan impact secara horizontal. Dari metode penulisan tersebut maka akan dihasilkan model pemetaan, yakni: High-High (HH), High-Medium(HM), High-Low (HL), Medium-High (MH), Medium-Medium (MM), Medium-Low (ML), Low-High (LH), Low-Medium (LM), dan Low-Low (LL). Keterangan pada Probability-Impact Matrix: angka menunjukkan nomor requirement yang direkomendasikan dan huruf melambangkan identifikasi resiko pada requirement yang direkomendasikan. Penggolongan requirement terhadap Probability-Impact Matrix dapat dilihat pada Tabel 9.

Tabel 9 Probability-Impact Matrix

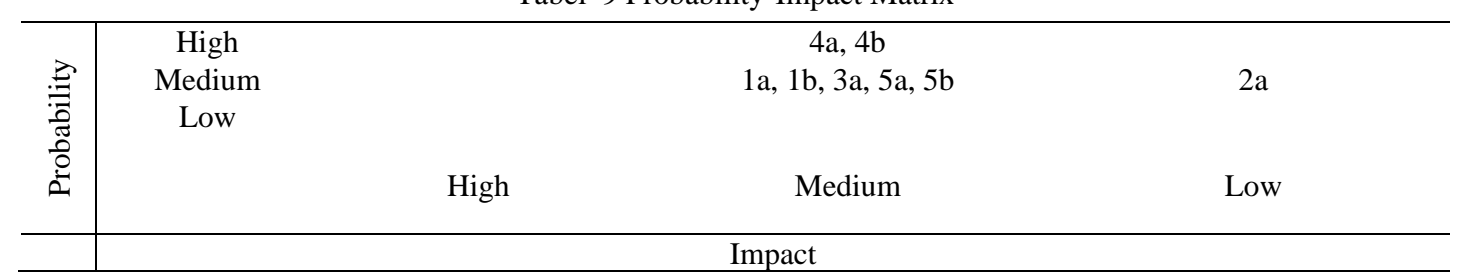

Berdasarkan pada probability Impact-Matrix di atas maka dari hasil analisis resiko didapatkan hasil sebagai berikut:

- Kriteria High Medium

Kriteria ini menunjukkan tingkat resiko yang diterima akan sangat tinggi jika rekomendasi tidak diterapkan dan dampak yang diterima cukup berpengaruh namun tidak menggangu kinerja sistem maupun perusahaan. Terdapat 2 resiko pada kriteria HM yakni 4a mengenai kurangnya inisiatif untuk berbagi pengetahuan antar pengguna dan $4 \mathrm{~b}$ mengenai kurangnya direktori pengetahuan yang berguna untuk perusahaan. Kurangnya inisiatif untuk berbagi pengetahuan akan memberikan dampak buruk kepada KMS Lentera yang memang dibuat untuk berbagi pengetahuan oleh para penggunanya sehingga diharapkan akan memberikan nilai tambah pada kulitas kerja mereka, sehingga notifikasi dan peringatan untuk mengirim pengetahuan sangat penting untuk mengingatkan pengguna KMS akan kewajiban mereka. Hal ini erat kaitannya dengan poin $4 \mathrm{~b}$ dimana direktori penyimpanan pengetahuan akan menjadi sedikit jika pengetahuan yang masuk relatif sedikit dikarenakan kurangnya perhatian mereka kepada KMS tersebut. Hal ini tentu akan membuat perusahaan menjadi kewalahan jika akan dilakukan penggalian pengetahuan di masa yang akan datang, dikarenakan pencarian pengetahuan akan dimulai dari dasar lagi dikarenakan tidak adanya data yang tersimpan di direktori perusahaan.

- $\quad$ Kriteria Medium

Medium Kriteria ini menunjukkan tingkat resiko yang diterima akan cukup tinggi apabila rekomendasi tidak diterapkan dan dampak yang diterima cukup berpengaruh namun tidak mengganggu kinerja sistem maupun perusahaan. Terdapat 5 resiko pada kriteria MM yakni 1a mengenai menghambat penyampaian pengetahuan untuk pegawai baru, $1 \mathrm{~b}$ mengenai mengurangi direktori pengetahuan untuk penelitian di masa yang akan datang, 3a mengenai memperlambat pekerjaan, 5a mengenai kurangnya motivasi untuk berbagi pengetahuan antar pengguna, dan $5 \mathrm{~b}$ mengenai kurangnya direktori pengetahuan yang berguna untuk perusahaan. Pada poin 1a dengan membatasi waktu penyimpanan maka akan membatasi pengguna yang dapat mengakses berbagi pengetahuan tersebut dikarenakan jika di masa depan terdapat pengguna yang bergabung maka orang yang bersangkutan tidak akan bisa mengakses fasilitas berbagi pengetahuan tersebut dikarenakan telah dihapus berdasarkan waktu penyajian pengetahuan. Pada poin $1 \mathrm{~b}$ hampir sama dengan poin $4 \mathrm{~b}$ pada kriteria HM yang membedakannya adalah pada poin $1 \mathrm{~b}$ pengetahuan tersebut sudah dibagikan kepada pengguna yang ada, namun masih dibatasi dalam waktu tertentu. Poin 3a yakni 
memperlambat pekerjaan dikarenakan dengan adanya persetujuan dari general manager yang memiliki level dan prioritas lebih tinggi dari admin maka tidak perlu lagi dibutuhkan persetujuan oleh admin. Poin 5a mengenai kurangnya motivasi untuk berbagi pengetahuan hampir sama dengan poin 4a perbedaannya adalah pada poin 5a motivasi yang didapatkan berdasarkan poin dari posting yang didapatkan, sedangkan 4a adalah berdasarkan kewajiban bagi setiap pengguna untuk mengirim pengetahuan. Poin $5 \mathrm{~b}$ yakni kurangnya direktori pengetahuan yang berguna bagi perusahaan yang disebabkan karena pengiriman pengetahuan yang relatif kurang, sehingga dibutuhkan imbalan/intensif berdasarkan jumlah postingan yang digunakan sebagai penambah semangat bagi pengguna dalam berbagi pengetahuan dan belajar.

- Kriteria Medium Low

Kriteria ini menunjukkan tingkat resiko yang diterima akan cukup tinggi apabila rekomendasi tidak diterapkan dan dampak yang diterima sangat kecil sehingga tidak terlalu berpengaruh pada kinerja sistem dan perusahaan. Terdapat 1 resiko pada kriteria ML, yakni 2a mengenai terhapusnya data mengenai ide dan inovasi yang mungkin berguna dimasa depan. Resiko ini termasuk medium dikarenakan ide dan inovasi yang telah disubmit memang akan dicek dan diseleksi kualitasnya yang pada akhirnya akan diputuskan untuk dipergunakan atau tidak oleh perusahaan nantinya, namun ada baiknya jika ide dan inovasi yang telah dibuat disimpan pada direktori perusahaan sebagai cadangan ide maupun inovasi yang jika memungkinkan dapat diseleksi lagi. Adapun cara untuk menjaga kualitas kiriman pengetahuan maupun ide dan inovasi dari setiap pengguna adalah dengan menyeleksi sumber dan isi dari posting itu sendiri, dimulai dari materi yang disampaikan dengan bahasa dan ejaan yang baik dan benar, gambar dan video yang sesuai, juga ikut menyertakan referensi dari sumber-sumber terpercaya.

\section{Usulan Urutan Pelaksanaan Rekomendasi}

Berdasarkan hasil analisa dan metode yang telah digunakan, penulis memberikan beberapa rekomendasi, yakni menghilangkan persetujuan dari admin jika persetujuan sudah diberikan oleh general manager setelah submit ide/inovasi dilakukan, membuat fitur notifikasi untuk mengingatkan pengguna mengenai kewajiban mereka akan mengirimkan pengetahuan, dan menghilangkan fitur penentuan periode penyimpanan. Usulan untuk urutan pelaksanaan rekomendasi dibagi menjadi dua, yakni perhitungan antara rank pada Fit/Gap Analysis dengan probability dan impact pada risk analysis serta usulan untuk untuk urutan pelaksanaan rekomendasi berdasarkan keterkaitan antara setiap kebutuhan.

Perhitungan untuk menentukan rank pada Fit/Gap Analysis dengan probability, impact, dan risk analysis adalah sebagai berikut:

- $\quad$ Poin Rank pada Fit/Gap Analysis

o Rank High dengan Degree of Fit Gap :6

o Rank High dengan Degree of Fit Partial :5

o Rank Medium dengan Degree of Fit Gap :4

o Rank Medium dengan Degree of Fit Partial :3

o Rank Low dengan Degree of Fit Gap :2

o Rank Low dengan Degree of Fit Partial :1

- $\quad$ Poin Risk Analysis (High: 3, Medium: 2, dan Low:1)

o Kriteria High High $(\mathrm{HH}) \quad: 6$

o Kriteria High Medium (HM) :5

o Kriteria High Low (HL) :4

o Kriteria Medium High (MH) :5

o $\quad$ Kriteria Medium Medium (MM) :4

o $\quad$ Kriteria Medium Low (ML) :3

o $\quad$ Kriteria Low High (LH) :4

o $\quad$ Kriteria Low Medium (LM) :3 
o $\quad$ Kriteria Low Low (LL)

$: 2$

Total poin secara keseluruhan didapatkan dari poin rank pada Fit/Gap Analysis dan ratarata poin pada probabilty dan impact pada risk analysis dengan Persamaan 1 dan 2.

Total Poin $=$ Rank in Fit Gap Analysis $+\bar{x}$

$$
\bar{x}=\frac{x 1+x 2+\cdots+x n}{n}
$$

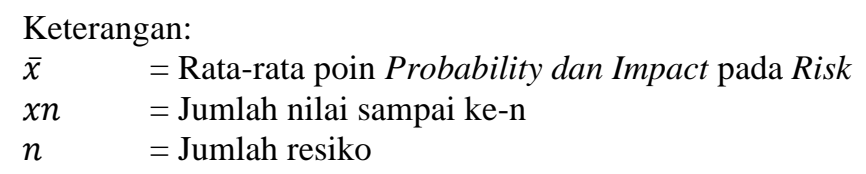

Dengan Persamaan 1 dan 2, dihasilkan perhitungan antara rank pada Fit/Gap Analysis, probability, dan impact seperti pada Tabel 10. Maka hasil keseluruhannya akan terlihat pada Tabel 11.

Tabel 10 Perhitungan rank pada Fit/Gap Analysis, probability dan impact

\begin{tabular}{cllccc}
\hline No & \multicolumn{1}{c}{ Recomendation } & \multicolumn{1}{c}{ Requirement } & $\begin{array}{c}\text { Rank in Fit/Gap } \\
\text { Analysis (Poin) }\end{array}$ & $\begin{array}{c}\text { Probability dan Impact } \\
\text { in Risk Analysis (Poin) }\end{array}$ & $\begin{array}{c}\text { Total } \\
\text { Poin }\end{array}$ \\
\hline 1 & $\begin{array}{l}\text { Melihat pentingnya } \\
\text { knowledge tersimpan, } \\
\text { direkomendasikan tidak ada } \\
\text { penentuan periode } \\
\text { penyimpanan }\end{array}$ & $\begin{array}{l}\text { Periode penyimpanan: } \\
\text { Tentukan periode }\end{array}$ & LG(2) & a. MM(4) & 6 \\
retensi saat mendaftar & bengetahuan & & & $(2+4)$ \\
& & & & \\
\hline
\end{tabular}

Tabel 11 Hasil perhitungan rank pada Fit/Gap Analysis, probability dan impact

\begin{tabular}{|c|c|c|c|c|}
\hline Rank & Recomendation & Requirement & $\begin{array}{l}\text { Total } \\
\text { Poin }\end{array}$ & $\begin{array}{c}\text { Activity } \\
\text { No }\end{array}$ \\
\hline 1 & $\begin{array}{l}\text { Di rekomendasikan adanya notifikasi atau peringatan } \\
\text { ke user apabila belum pernah sharing knowledge/idea } \\
\text { dan terintegerasi ke email pengguna. }\end{array}$ & $\begin{array}{l}\text { Melihat daftar knowledge/Idea } \\
\text { user yang sudah di publish }\end{array}$ & 10 & 4 \\
\hline 2 & $\begin{array}{l}\text { Direkomendasikan untuk menghilangkan proses } \\
\text { approval oleh admin, karena sudah dilakukan } \\
\text { approval oleh General Manager dan akan membuat } \\
\text { proses approval lebih panjang dan lama }\end{array}$ & $\begin{array}{l}\text { Meminta Approval } \\
\text { Administrator }\end{array}$ & 9 & 3 \\
\hline 3 & $\begin{array}{l}\text { Di rekomendasikan untuk membuat Program } \\
\text { Reward/Insentif bagi yang sudah mengumpulkan } \\
\text { Poin dengan jumlah tertentu, agar user termotivasi } \\
\text { untuk terus melakukan sharing knowledge dan terus } \\
\text { belajar }\end{array}$ & Melihat Poin/Mileage & 9 & 5 \\
\hline 4 & $\begin{array}{l}\text { Melihat pentingnya knowledge tersimpan, } \\
\text { direkomendasikan tidak ada penentuan periode } \\
\text { penyimpanan }\end{array}$ & $\begin{array}{l}\text { Periode penyimpanan: } \\
\text { Tentukan periode retensi saat } \\
\text { mendaftar pengetahuan }\end{array}$ & 6 & 1 \\
\hline 5 & $\begin{array}{l}\text { Melihat pentingnya Idea/Inovasi tersimpan, } \\
\text { direkomendasikan tidak ada penentuan periode } \\
\text { penyimpanan }\end{array}$ & $\begin{array}{l}\text { Periode penyimpanan: } \\
\text { Tentukan periode retensi saat } \\
\text { mendaftar pengetahuan }\end{array}$ & 5 & 2 \\
\hline
\end{tabular}

\section{Tindak Lanjut Rekomendasi Berdasarkan Usulan Urutan Pelaksanaannya}

\section{Fitur Notifikasi Posting}

Fitur notifikasi akan muncul sebagai pengingat pengguna untuk melakukan posting mingguan dan akan muncul jika sudah mendekati 4 hari sebelum batas waktu yang ditentukan. Kegunaan dari posting ini selain untuk mengingatkan kewajiban posting para penggunanya, juga sebagai cara untuk mendorong $73.3 \%$ para pengguna pasif untuk lebih aktif dalam melakukan posting sehingga perputaran berbagi pengetahuan yang ada dalam Lentera dapat terus dilakukan sebagaimana mestinya. Selanjutnya, direkomendasikan untuk membuat koneksi antara sistem notifikasi tersebut agar terintegrasi ke surelpengguna sehingga notifikasi yang diterima tidak hanya dari aplikasi KMS saja melainkan juga surel. 


\section{Menyederhanakan Sistem Approval Idea/Inovasi}

Berdasarkan penelitian, dapat disimpulkan bahwa menunggu persetujuan dari admin Lentera setelah mendapatkan approval dari general manager akan membuang banyak waktu dikarenakan wewenang general manager yang dapat melakukan refuse, reject, dan delete kepada idea/informasi adalah poin terpenting dan sudah cukup sebagai akhir prosesnya. Dengan adanya rekomendasi ini, diharapkan proses kerja sistem menjadi lebih sederhana tanpa mengurangi kualitasnya sedikit pun. Diagram alir rancangan rekomendasi sistem approval untuk ide/inovasi dapat dilihat pada Gambar 3.

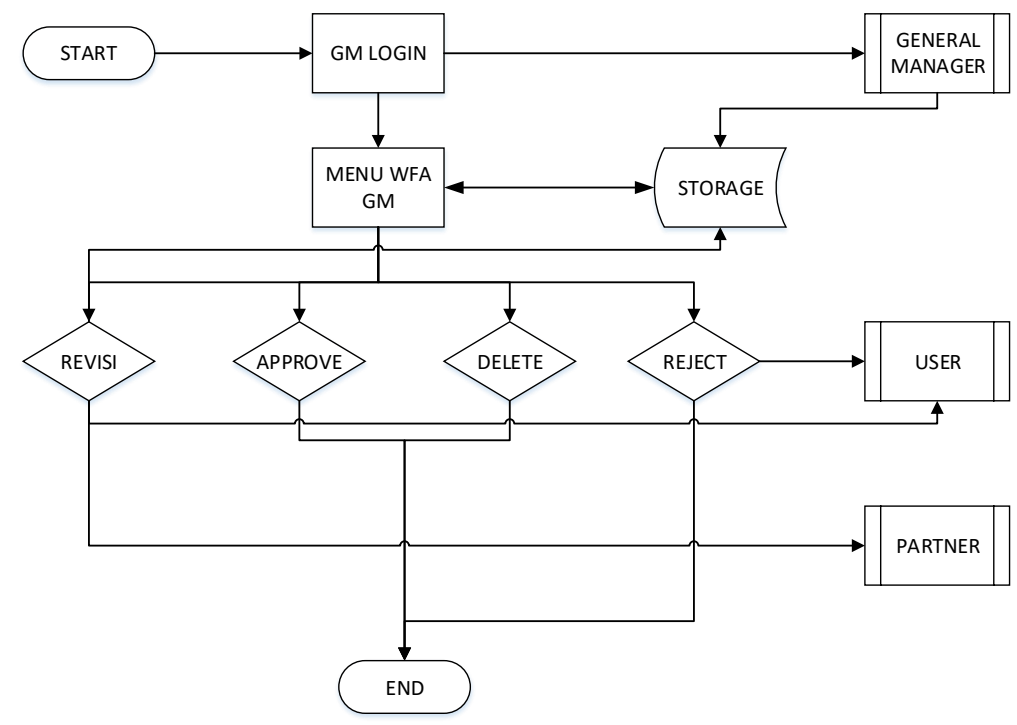

Gambar 3 Diagram alir rancangan sistem approval.

Dari diagram alir di atas dapat dilihat jika general manager masih tetap melakukan aktivitasnya untuk melakukan revisi, approve, delete dan reject terhadap ide dan inovasi yang diberikan oleh pengguna seperti biasa tanpa ada perubahan dan langsung mengakhiri semua aktivitas yang dilakukan dan mengirim notifikasi langsung kepada pengguna setelah general manager mengambil keputusan kepada ide dan inovasi yang telah dimasukkan, yang membedakan adalah dihilangkannya aktivitas admin untuk melakukan approval pada ide dan inovasi yang telah terlebih dahulu diberikan approval oleh general manager. Dengan ini, diharapkan sistem dapat bekerja lebih singkat dan efisien tanpa mengurangi kualitasnya.

\section{Membuat Program Reward/Insentif}

Program reward/insentif direncanakan untuk pengguna yang melakukan posting secara teratur sehingga mendapatkan poin yang mencukupi untuk memperoleh reward/insentif tersebut. Pada program ini terdapat milestone yang menjadi acuan seberapa besar poin yang diperoleh oleh pengguna. Rancangan reward/insentif dapat dilihat pada Gambar 4. Berdasarkan gambar tersebut dapat dilihat bahwa pengguna yang secara aktif melakukan posting akan dapat meningkatkan poinnya secara berkala tergantung konten yang mereka bagikan maupun kontribusi untuk ide dan inovasi bagi perusahaan. Dengan milestone ini diharapkan agar pengguna dapat melihat dengan jelas goal yang akan mereka capai setelah melakukan kontribusi pada KMS Lentera dan dapat mendorong mereka untuk terus proaktif dalam sharing dan belajar. Rekomendasi ini sangat dianjurkan untuk dilakukan dikarenakan dapat mendorong 73.3\% pengguna yang pasif sehingga mereka menjadi lebih proaktif dan juga meningkatkan jumlah posting knowledge oleh para pengguna secara intensif dikarenakan mereka akan bersaing antara satu sama lain untuk mendapatkan reward yang telah dipersiapkan. Untuk biaya insentifnya sendiri diusulkan adanya koordinasi dari bagian keuangan HCM dan Top Level Management untuk perencanaannya. 


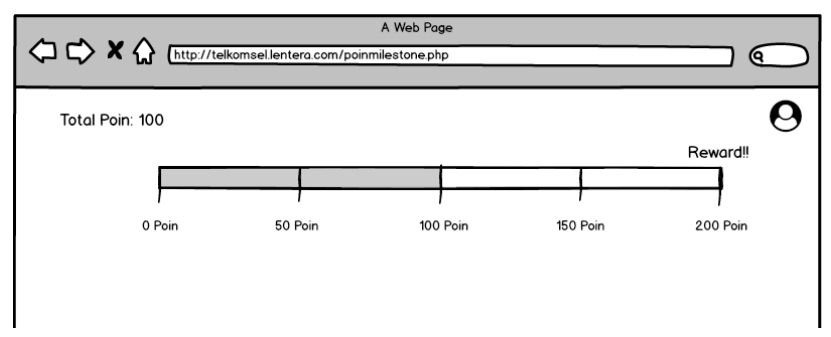

Gambar 4 Rancangan reward/insentif.

\section{Menghilangkan fitur penentuan periode penyimpanan untuk pengetahuan}

Menghilangkan fitur periode penyimpanan untuk pengetahuan dimaksudkan agar pengetahuan tersebut dapat digunakan dalam jangka panjang sehingga pengguna baru juga mendapat edukasi dengan membaca pengetahuan yang ada pada KMS tersebut. Diagram alir rekomendasi untuk mengirim pengetahuan pada KMS Lentera dapat dilihat pada Gambar 5.

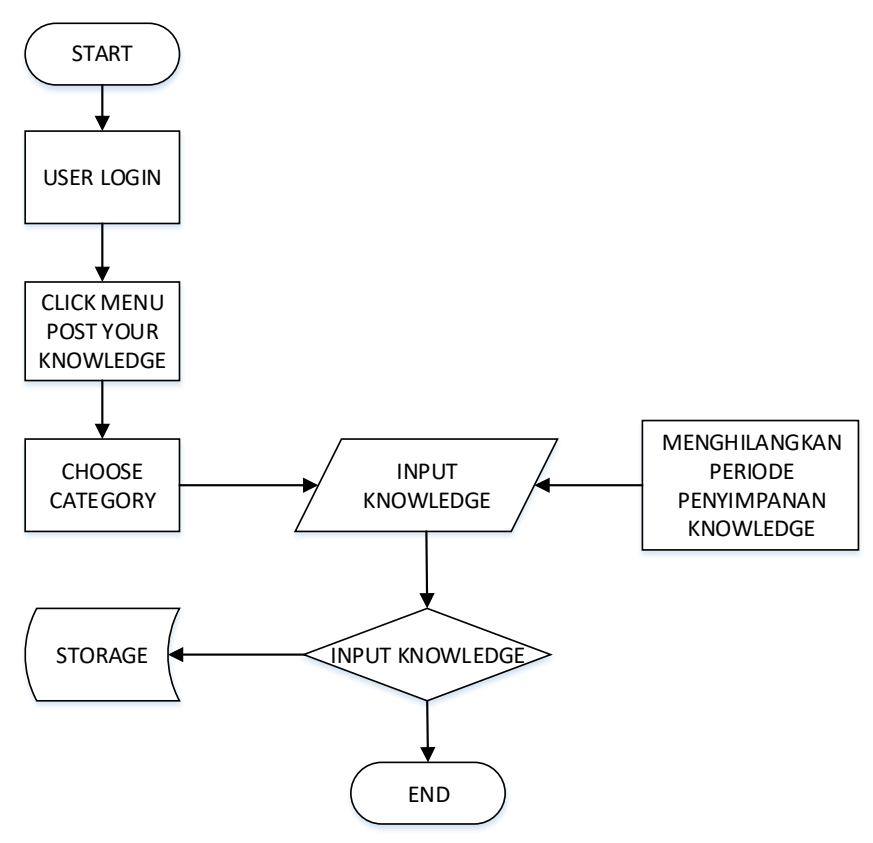

Gambar 5 Diagram alir rekomendasi mengirim pengetahuan.

Dari Gambar 5 dapat dilihat bahwa proses yang dilakukan oleh pengguna adalah sama seperti sebelumnya, namun pada saat memasukkan pengetahuan pengguna tidak perlu lagi mengisi waktu atau periode untuk menampilkan pengetahuan yang mereka kirim pada aplikasi Lentera.

\section{Menghilangkan fitur penentuan periode penyimpanan untuk Ide dan Inovasi}

Menghilangkan fitur periode penyimpanan untuk ide dan inovasi dimaksudkan agar ide dan inovasi yang telah dikirim tidak hilang begitu saja, namun dapat digunakan sebagai referensi di masa mendatang. Diagram alir rekomendasi untuk posting Ide dan Inovasi pada KMS Lentera dapat dilihat pada Gambar 6.

Berdasarkan Gambar 6 dapat dilihat bahwa proses yang dilakukan pengguna dalam melakukan submit ide/inovasi masih sama seperti sebelumnya namun terdapat perubahan pada saat memasukkan ide pada idea factory yang mana mereka tidak perlu lagi mengisi periode waktu penyimpanan ide/inovasi yang sudah mereka kirim. 


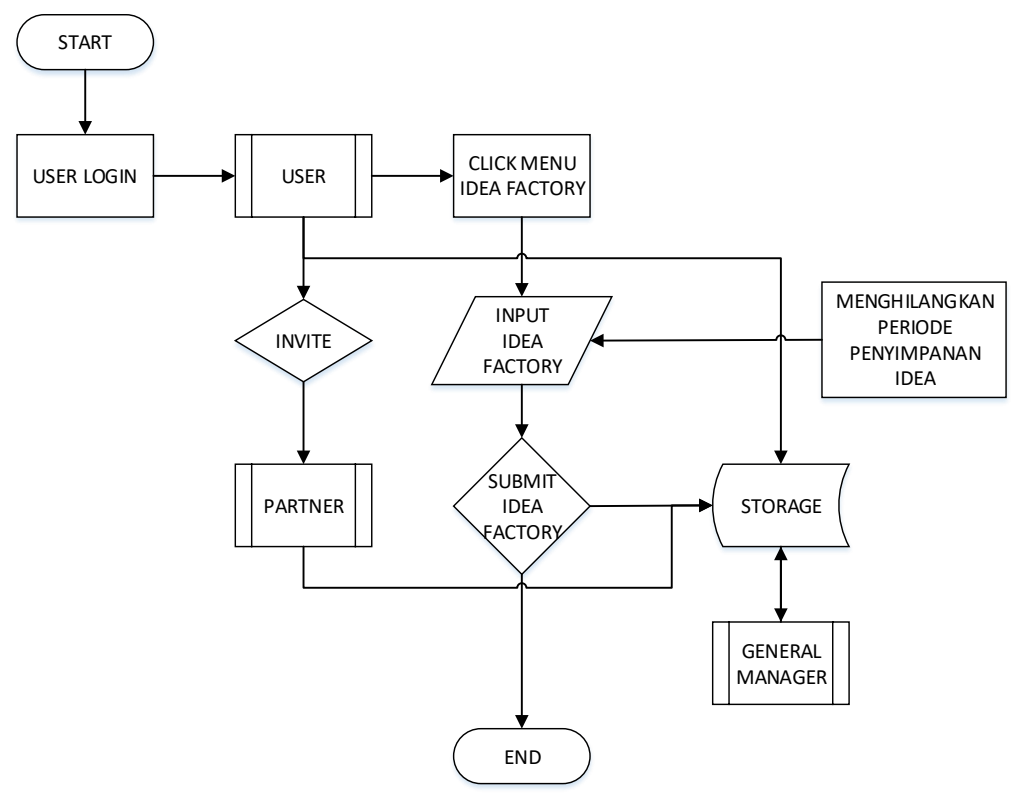

Gambar 6 Flowchart rekomendasi posting idea/inovasi.

\section{SIMPULAN}

Berdasarkan hasil evaluasi yang telah dilakukan penulis dengan menggunakan metode Fit/Gap Analysis dan Risk Analysis pada KMS Lentera PT Telkom, dapat disimpulkan bahwa KMS yang telah diimplementasikan oleh PT Telkomsel memiliki degree of fit sebesar $80 \%$ (20 requirement), degree of gap 8\% (2 requirement), dan degree of partial sebesar $12 \%$ (3 requirement). Terdapat 3 requirement yang dikategorikan sebagai partial gap, yakni meminta approval administrator, melihat daftar knowledgelidea pengguna yang sudah di publish, dan melihat point/mileage. Serta 2 requirement yang termasuk dalam kategori gap, yakni periode penyimpanan: Tentukan periode retensi saat mendaftar pengetahuan dan Periode penyimpanan: Tentukan periode retensi saat mendaftar pengetahuan. Berdasarkan hasil dari risk analysis diperoleh 8 dengan tingkat probability dan impact yang berbeda-beda. Berikut kategorinya, 2 risk dengan kategori High Medium, 5 risk dengan kategori Medium Medium, dan 1 risk dengan kategori Medium Low.

\section{DAFTAR PUSTAKA}

Jo Jackson M, Helms MM, Ahmadi M. 2011. Quality as a gap analysis of college students' expectations. Quality Assurance in Education. 19(4): 392- 412.

Dalkir K dan Beaulieu M. 2017. Knowledge Management in Theory and Practice 3rd Edition. Cambridge (UK): The MIT Press.

Dalkir K. 2011. Knowledge Management in Theory and Practice 2nd Edition. Cambridge (UK): The MIT Press.

Nazari K dan Emami M. 2012. Knowledge management: from theory to practice. Australian Journal of Business and Management Research. 1(11): 22-30.

Sari WK dan Tania KD. 2014. Penerapan knowledge management system (KMS) berbasis web studi kasus bagian teknisi dan jaringan Fakultas Ilmu Komputer Universitas Sriwijaya. Jurnal Sistem Informasi. 6(2): 681-688.

Pajk D dan Kovacic A. 2013. Fit gap analysis: the role of business process reference model. Economic and Business Review. 15(4): 319-328.

Verma B dan Dhanda M. 2016. Risk analysis of software schedule based on simulation. International Journal for Innovative Research in Science \& Technology. 3(1): 71-77. 